\title{
WYKORZYSTANIE METODY 8D DO ROZWIĄZANIA PROBLEMU JAKOŚCIOWEGO
}

\author{
Andrzej Pacana, Karolina Czerwińska \\ Politechnika Rzeszowska im. Ignacego Łukasiewicza \\ Wydział Budowy Maszyn i Lotnictwa
}

\begin{abstract}
Streszczenie: Celem artykułu jest analiza niezgodności wyrobu przedstawionej w związ$\mathrm{ku} \mathrm{z}$ reklamacją klienta, tj. niedostatecznego przylegania folii okleiny do ramiaka pionowego skrzydła drzwi wewnątrzlokalowych STILE. W publikacji przeanalizowano wykorzystanie jednej z metod zarządzania jakością, jaką jest metoda $8 \mathrm{D}$, do rozwiązywania problemu w obszarze jakości w przedsiębiorstwie ERKADO, celem jego usprawnienia. Ideą zastosowanej metody jest prawidłowe zidentyfikowanie przyczyn powstania problemu, a także zaaplikowanie takich działań korygujących, aby zapobiec ponownemu pojawieniu się problemu.
\end{abstract}

Słowa kluczowe: metoda 8D, burza mózgów, diagram Pareto-Lorenza, zarządzanie jakością, metody zarządzania jakością

DOI: $10.17512 /$ znpcz.2017.4.2.07

\section{Wprowadzenie}

Proces produkcyjny w swojej istocie od zawsze narażony jest na pojawianie się w nim błędów, które wywoływane są nie zawsze łatwymi do zidentyfikowania przyczynami. Błędy, które mogą pojawić się bądź istnieć w procesie, można wykryć między innymi przy pomocy znanych metod zarządzania jakością, które stwarzają możliwość kontrolowania procesu na każdym etapie wytwarzania wyrobu. Obserwacja procesu produkcji stwarza szybką możliwość reakcji na wszystkie rozbieżności, jakie występują między planem realizacji a wykonaniem określonego zamówienia. Pojawiające się niezgodności nakłaniają do wprowa-dzania zmian w działaniach produkcyjnych, aby uzyskać cel, jakim jest poprawa wydajności produkcji wyrobu, a także minimalizacja liczby wystę-powania błędów. Planowana i realizowana w procesie produkcyjnym kontrola stwarza także możliwość sprawdzenia, czy w trakcie produkcji mają miejsce jakieś istotne dla niego problemy (np. Ćwiklicki, Obora 2009; Szczepańska 2009). Pojawiającym się niezgodnościom można zapobiec jeszcze przed rozpoczęciem uruchomienia bądź też w momencie, gdy proces został już uruchomiony. Kiedy w procesie produkcji występują problemy, istnieje możliwość rozwiązywania ich w bieżący sposób, co przyczynia się do znacznego obniżenia kosztów produkcji, a jednocześnie nie wpływa na czasochłonność pracy. W sytuacji, w której w procesie produkcyjnym powstają nieuniknione błędy i w związku z tym produkt nie uzyskuje statusu określającego spełnienie wymagań, znacznie zwiększają się koszty produkcji (Midor 2014, s. 163; Dahlgaard, Kristen, Kanji 2000). 
Aby zapewnić systematyczny oraz uporządkowany sposób rozwiązywania pojawiających się problemów, a także ich przejrzystego dokumentowania zalecana jest powszechnie stosowana metoda 8D (Huber 2007, s. 15). Metoda 8D zawiera w sobie wiele narzędzi służących do zarządzania jakością, z tego względu pozwala na dogłębne przeanalizowanie przyczyn zaistniałych niezgodności (Łuczak, Matuszak-Flejszman 2007, s. 272).

Obecnie firmy funkcjonujące na rynku konkurują ze sobą, stosując narzędzia, które zoptymalizują ich pracę, pozwolą udoskonalać procesy produkcyjne oraz jakość wyrobów (Rumocka 2016, s. 169). Jedną z firm dążących do optymalizacji swoich wyrobów jest firma ERKADO, zajmująca się produkcją drzwi wewnętrznych: ramiakowych, płytowych, hybrydowych, szklanych, pożarowych, dwuskrzydłowych, drzwi z systemem przesuwnym, drzwi zewnętrznych i oścież-nic, oraz prowadzeniem działalności handlowej. Obszerna działalność firmy ERKADO sprawia, iż zaczęła ona przywiązywać dużą wagę do efektywnego zarządzania projakościowego.

Celem artykułu jest analiza zaistniałej niezgodności wyrobu - niedostatecznego przylegania okleiny do krawędzi ramiaka pionowego skrzydła drzwiowego STILE - oraz zapobiegnięcie jej ponownego wystąpienia. W tym przypadku zaproponowano wykorzystanie metody $8 \mathrm{D}$ do rozwiązania problemu związanego $\mathrm{z}$ reklamacją klienta, gdyż stanowi ona metodologię rozwiązywania problemów w celu polepszenia produktu oraz procesu. Przewagą metody 8D w stosunku do pozostałych metod zarządzania jakością jest możliwość zastosowania jej do analizy oraz rozwiązania problemów wewnętrznych oraz zewnętrznych, związanych z działaniem firmy, których przyczyny nie są znane bądź ich znaczenie nie zostało uprzednio ustalone. W metodzie tej, w przeciwieństwie do innych schematów postępowania z problemami jakościowymi, wskazać należy na pracę zespołową, która jest istotna dla powodzenia poszczególnych etapów działań.

\section{Istota zastosowania metody $8 \mathrm{D}$}

Metody zarządzania jakością umożliwiają rozwiązywanie zadań związanych z zarządzaniem jakością w całym cyklu życia analizowanego wyrobu. Do charakterystycznych cech metod zarządzania jakością należy: planowość, powtarzalność oraz oparcie na podstawach naukowych. W trakcie stosowania metod mających na celu wspomaganie zarządzania jakością wykorzystywane są dane wcześniej zebrane przy użyciu narzędzi zarządzania jakością (Mazur, Gołaś 2010, s. 26; Antosz, Pacana, Stadnicka, Zielecki 2013).

Metoda 8D to zespołowe i wieloetapowe działania, odwołujące się na każdym etapie analizy do innych narzędzi oraz metod z zakresu zarządzania jakością. Toteż 8D nie stanowi kolejnej metody w zarządzaniu jakością, ale jest pewnym uporządkowanym procesem, tworzącym schemat postępowania (Babuśka, Kluczek 2009, s. 7). Proces postępowania według 8 kroków powinien dostarczyć rozwiązania problemu jakościowego, przy użyciu różnych metod oraz narzędzi doskonalenia jakości (Łuczak, Matuszak-Flejszman 2007, s. 272). 
Stosowanie przedstawionej metody ułatwia określenie przyczyn wystąpienia zaistniałej niezgodności, a także pozwala na wskazanie sposobu rozwiązania problemu i dodatkowo stwarza możliwość weryfikacji dokonanych działań (Łasiński 2007). Istotnym jest, iż w metodzie 8D, w odróżnieniu od innych schematów postępowania przy rozwiązywaniu problemów, należy kłaść nacisk na pracę zespołową, będącą ważną dla powodzenia etapów działań, które wymagają znajomości nie tylko samego procesu produkcyjnego czy wyrobu, ale również specyfiki całego przedsiębiorstwa (Babica, Pająk 2006b, s. 20).

Etapy działań w metodyce 8D przedstawiono w Tabeli 1, zgodnie z podejściem Łuczaka oraz Maćkiewicza. Babica i Pająk wyszczególnili narzędzia oraz techniki, które w praktyce przedsiębiorstw produkcyjnych są najpowszechniej stosowane na poszczególnych etapach realizacji metody $8 \mathrm{D}$.

Tabela 1. Propozycja zastosowania wybranych technik i narzędzi jakości na poszczególnych etapach metody $8 D$

\begin{tabular}{|c|c|c|}
\hline $\begin{array}{l}\text { Etap } \\
\text { metody 8D }\end{array}$ & Nazwa etapu & $\begin{array}{c}\text { Narzędzia i techniki wspierające } \\
\text { realizację etapu }\end{array}$ \\
\hline D1 & Powołanie zespołu 8D & $\begin{array}{l}\text { Poprzednie raporty 8D, diagram } \\
\text { Ishikawy, diagram relacji }\end{array}$ \\
\hline D2 & Zdefiniowanie problemu & $\begin{array}{l}\text { Poprzednie raporty 8D, burza mózgów, } \\
\text { arkusz kontrolny, analiza porównawcza, } \\
\text { histogram, diagram Ishikawy, FMEA, } \\
\text { wykres Pareto, metoda ABCD, zdolność } \\
\text { procesu, dane SPC }\end{array}$ \\
\hline D3 & $\begin{array}{l}\text { Zdefiniowanie } \\
\text { i wdrożenie tymczasowych } \\
\text { działań powstrzymujących }\end{array}$ & $\begin{array}{l}\text { Poprzednie raporty 8D, analiza porów- } \\
\text { nawcza, analiza ryzyka, analiza FMEA, } \\
\text { zdolność procesu, wykres Gantta }\end{array}$ \\
\hline D4 & $\begin{array}{l}\text { Identyfikacja potencjalnych } \\
\text { przyczyn problemu }\end{array}$ & $\begin{array}{l}\text { Poprzednie raporty 8D, analiza FMEA, } \\
\text { diagram Ishikawy, nowe narzędzia } \\
\text { zarządzania jakością (diagram relacji, } \\
\text { diagram macierzowy i inne) }\end{array}$ \\
\hline D5 & $\begin{array}{l}\text { Określenie działań } \\
\text { korygujących }\end{array}$ & Poprzednie raporty $8 \mathrm{D}$, metoda $A B C D$ \\
\hline D6 & $\begin{array}{l}\text { Wdrożenie działań } \\
\text { korygujących }\end{array}$ & $\begin{array}{l}\text { Poprzednie raporty 8D, schemat } \\
\text { blokowy, wykres PDPC, wykres Gantta }\end{array}$ \\
\hline D7 & $\begin{array}{l}\text { Zapobieganie ponownemu } \\
\text { wystąpieniu }\end{array}$ & $\begin{array}{l}\text { Poprzednie raporty } 8 \mathrm{D} \text {, analizy FMEA, } \\
\text { wykres Pareto, dane SPC }\end{array}$ \\
\hline D8 & $\begin{array}{l}\text { Raport o zakończeniu } \\
\text { działań }\end{array}$ & Poprzednie raporty 8D \\
\hline
\end{tabular}

Źródło: Opracowanie własne na podstawie (Luczak, Maćkiewicz 2006, s. 35; Babica, Pająk 2006b, s. 37) 
Metoda 8D powinna być używana do analizy oraz do rozwiązywania nie tylko problemów zewnętrznych przedsiębiorstwa, tj. np. reklamacji od klientów, ale również wewnętrznych, które są ważne $\mathrm{z}$ punktu widzenia kosztów jakości (Łuczak, Maćkiewicz 2006, s. 37; Francik, Pudło 2016, s. 23).

\section{Analiza problemu z wykorzystaniem metody 8D}

\section{Ogólna charakterystyka problemu}

Problem dotyczy niedoklejenia taśmy Touchwood w ramiaku pionowym skrzydła drzwiowego wewnątrzlokalowego ramiakowego STILE produkowanego przez ERKADO Zbigniew Kozłowski na zlecenie klienta zewnętrznego. Niezgodność została wskazana przy pomocy strzałki na Fotografii 1 .

Produkowana część montowana jest do skrzydła drzwiowego wewnątrzlokalowego ramiakowego STILE jako jeden z elementów składowych. Przedstawiona niezgodność została wykryta przez klienta podczas rozpakowywania dostarczonego mu wyrobu. Klient natychmiast zgłosił zauważony błąd.

Niewielka niezgodność w postaci braku całkowitego przylegania okleiny GREKO do ramiaka z płyty MDF jest w stanie zagrozić prawidłowemu działaniu drzwi wewnętrznych. Niezgodność ta świadczy o tym, iż powierzchnie płyty i okleiny nie zostały połączone w odpowiedni sposób.

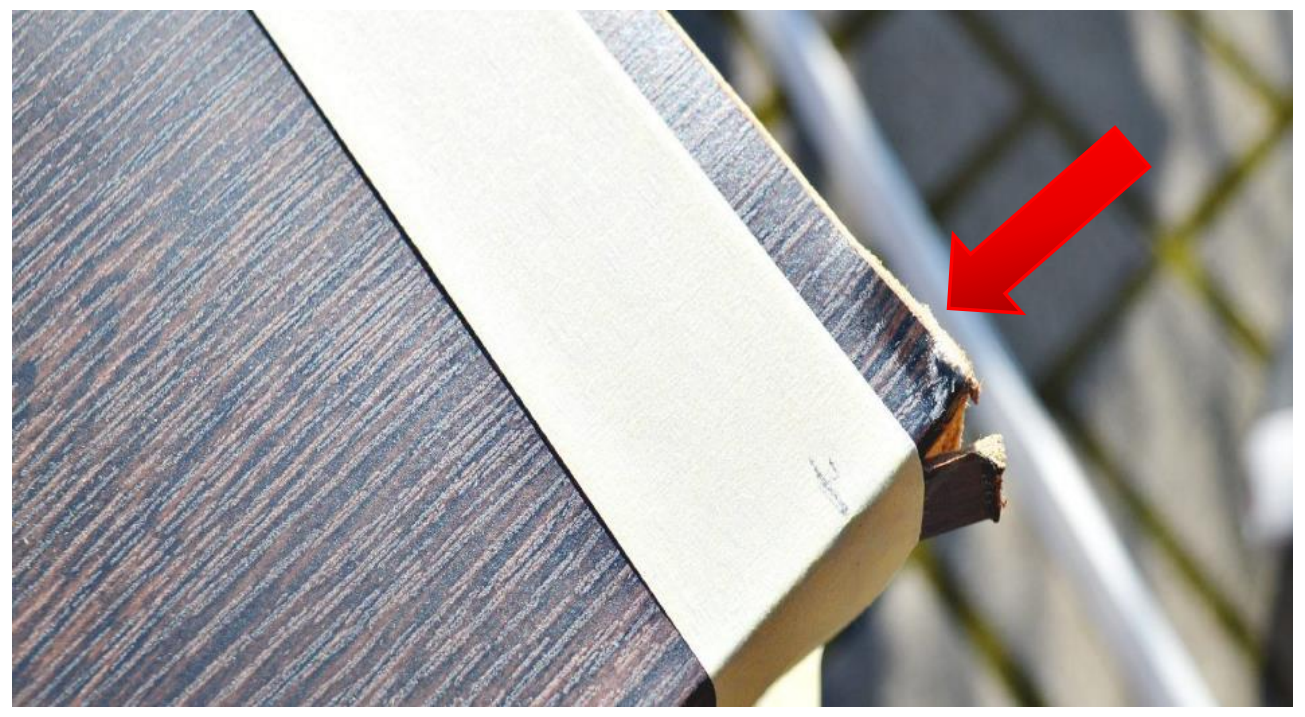

Fotografia 1. Zdjęcie przykładowej niezgodności - brak przylegania okleiny do krawędzi ramiaka pionowego skrzydła drzwiowego STILE

Źródło: Opracowanie własne na podstawie materiałów ERKADO Zbigniew Kozłowski 


\section{Krok D0 - przygotowanie do procesu 8D}

Osoba zatrudniona w dziale reklamacji sporządziła formularz reklamacyjny dotyczący rozpatrywanej niezgodności wyrobu po tym, jak klient znalazł i zgłosił brak całkowitego przylegania okleiny do ramiaka drzwi. W przedsiębiorstwie w przypadku wystąpienia niezgodności uzupełniany jest formularz, stanowiący punkt wyjściowy do przeprowadzenia analizy 8D. Jak można zaobserwować na Fotografii 1, problem ewidentnie zaistniał, odstawanie okleiny jest niedopuszczalne. Bezpośrednim odbiorcą procesu produkcji drzwi ramiakowych STILE, na których zauważono niezgodność, była firma zewnętrzna, będąca wieloletnim klientem ERKADO. Wyrób niezgodny został dostarczony do klienta, toteż zaistniała konieczność skontrolowania, czy inne drzwi tej serii posiadają niezgodności tego rodzaju.

W zaistniałej sytuacji wykorzystanie metody 8D jest uzasadnione.

\section{Krok D1 - powołanie zespołu 8D}

Do zespołu badającego problem zostały wybrane cztery osoby. Pierwszą powołaną osobą był kierownik zakładu. Jego udział był konieczny, gdyż to on sprawuje nadzór nad reklamacjami na wyroby zakładu, jest właścicielem procesu, przez co do jego kompetencji należy podejmowanie bądź zatwierdzanie kluczowych decyzji związanych ze wszystkimi działaniami realizowanymi w ramach procesu. Bez zgody kierownika zakładu nie byłoby możliwe przeprowadzenie kolejnych kroków metody 8D odnoszących się do wprowadzenia zmian do procesu produkcji drzwi ramiakowych STILE mających na celu jego naprawę oraz zapobieganie występowaniu braków w przyszłości.

Kolejną osobą wchodzącą w skład zespołu był kierownik wydziału „skrzydła STILE”, który został liderem zespołu. Zadanie lidera jest kluczowe, gdyż w jego gestii leży motywacja członków zespołu do aktywnego uczestnictwa w analizie. Lider zachęca podczas trwania sesji burzy mózgów do podawania przez członków jak największej liczby pomysłów. W jego gestii leży również dyscyplinowanie członków zespołu, by np. nie krytykowali rozwiązań podawanych przez inne osoby podczas burzy mózgów. Osoba sprawująca tę funkcję bez wątpienia posiada duże doświadczenie w przeprowadzaniu analiz z użyciem metody 8D. Jako kierownik wydziału posiada wiedzę na temat wymagań, jakie musi spełnić gotowy wyrób, zaczynając od etapu projektowania, a kończąc na dostarczeniu wyrobu do klienta. Lider powinien dokładne poinformować zespół o istocie analizowanego problemu, dodatkowo powinien ustalić harmonogram spotkań w zakresie przeprowadzenia metody 8D.

Kolejnymi osobami - trzecią i czwartą - wchodzącymi w skład zespołu byli dwaj technolodzy, których udział był zasadny, ze względu na fakt, iż znali oni metody wytwarzania badanych wyrobów. Osoby te musiały aktywnie uczestniczyć podczas prowadzenia analiz, opierając się na swoim doświadczeniu oraz wiedzy. Każdy z technologów zobowiązany został do przedstawiania jak największej liczby ewentualnych przyczyn wystąpienia niezgodności, wraz z pomysłami ich naprawy. 
Aktywność członków zespołu jest kluczowa dla poprawnego i owocnego przebiegu analizy. Członkowie zespołu mieli swobodny dostęp do dokumentacji technologicznej przebiegu procesu.

\section{Krok D2 - zdefiniowanie problemu}

Problem dotyczył nieprawidłowego nałożenia folii Touchwood na ramiak pionowy, wykorzystywany jako element składowy do skrzydła drzwi wewnątrzlokalowych ramiakowych STILE. Nieprawidłowe przyleganie okleiny do ramiaka zostało wykryte przez klienta $\mathrm{w}$ trakcie wypakowywania dostarczonych mu drzwi. Klient niezwłocznie zgłosił zauważoną niezgodność wyrobu. Odstawanie elementu okleiny jest niedopuszczalne i zabronione przez proces produkcyjny opracowany dla tego wyrobu.

W procesie oklejania powierzchni okleinami sztucznymi występuje konieczność oklejania bocznych, często wąskich powierzchni takim samym surowcem pod względem barwy, wzoru i faktury. W tym celu przedsiębiorstwa produkujące folie oraz okleiny sztuczne produkują również analogiczne wzory taśm obrzeżowych. Stosowana na linii produkcyjnej okleina na nośniku z folii poliestrowej o handlowej nazwie Touchwood stanowi jeden z rodzajów sztucznej okleiny poświęconej do wykańczania „na gotowo” bardzo gładkich, wąskich bądź szerokich (profilowych albo nie) powierzchni np. z płyt MDF. Tego rodzaju powierzchnie nie wymagają lakierowania.

Okleina sztuczna Touchwood posiada strukturę warstwową i składa się z czterech warstw (w kolejności od spodu okleiny):

- cienkiej warstwy kleju termoaktywnego (topliwego) służącego do przyklejenia okleiny Touchwood do płyty MDF ramiaka;

- nadruku naniesionego od spodu na błonę akrylową - warstwę trzecią - jednobarwny bądź wielobarwny, ze wzorami imitującymi barwę oraz rysunek drewna;

- bardzo cienkiej, grubości rzędu 0,03 mm, półprzeźroczystej akrylowej błony zewnętrznej;

- warstwy nośnej - foli poliestrowej, która pokrywa prawą stronę okleiny oraz która, odmiennie niż w pozostałych sztucznych okleinach, w trakcie nanoszenia okleiny na detale zostaje zdjęta i zwinięta na charakterystyczną rolkę odpadową.

W przedsiębiorstwie ERKADO do aplikowania folii Touchwood przystosowane są specjalne urządzenia: czopiarko-nakładarki do wąskich powierzchni, walcowe nakładarki do płaszczyzn, prasy membranowe służące do wykańczania powierzchni profilowych. Samo wykańczanie płaszczyzn trwa bardzo krótko, urządzenie (nakładarka) pracuje w trybie ciągłym. Technologia nanoszenia na linii produkcyjnej STILE jest opracowana w taki sposób, że nie ma potrzeby przycinania obrzeży okleiny. Otrzymane elementy są ostatecznie wykończone oraz gotowe do montażu.

Podczas prowadzenia analizy zaistniałego problemu dokonano drobiazgowych oględzin wyrobu. Zespół zebrał wszelkie niezbędne oraz wyczerpujące informacje, co miało na celu zrozumienie problemu. Problem wystąpił dla kilku sztuk ramiaków pionowych $\mathrm{z}$ tej serii produkcyjnej. Pojawienie się tego typu anomalii w pro- 
cesie produkcyjnym sprawiło bezpośrednio niezgodność dla klienta i wzbudziło wewnętrzne działania naprawcze $w$ firmie ERKADO. Podczas przeprowadzania analizy z użyciem metody 8D na bieżąco zespół informował klienta o postępach prac. Wszelkie ustalenia przekazywane były również właścicielowi procesu.

\section{Krok D3 - zdefiniowanie i wdrożenie tymczasowych działań powstrzymujących}

Zespół działający w ramach metody 8D po dokonaniu wstępnej analizy problemu podjął tymczasowe działania zaradcze, których celem było ograniczenie negatywnych skutków wykrytej nieciągłości wyrobu. Niezgodność wyrobu została przedstawiona kierownictwu firmy ERKADO. Powołany zespół przeprowadził rozmowy zarówno z pracownikami produkcyjnymi linii STILE, jak i osobami, które bezpośrednio nadzorują ich pracę. Zespół dokonał również „gemba walking”, czyli przejścia przez cały proces, w miejscu, gdzie jest on realizowany, by zrozumieć, co rzeczywiście się w nim dzieje, gdzie pojawiają się główne problemy, a także w celu uchwycenia rzeczywistej sytuacji na linii produkcyjnej.

Dla dalszej realizacji produkcji powołany zespół wprowadził zmiany dotyczące ilości topliwego kleju na okleinie GREKO oraz wykonał techniczny przegląd urządzenia Askla, w tym dokonał wymiany sprężyny do napinacza folii. Dodatkowo sprawdzono warunki atmosferyczne panujące na hali produkcyjnej, ze szczególnym uwzględnieniem parametru wilgotności. Wdrożone tymczasowe działania zapobiegawcze mają na celu zapobiegnięcie eskalacji problemu, dalszemu generowaniu wyrobów niezgodnych - braków, a co najgorsze - przekazaniu wyrobów niezgodnych klientowi. $Z$ tego względu pracownicy produkcyjni zostali powiadomieni o konieczności wzmożonej czujności na tym etapie procesu produkcji skrzydła drzwiowego.

W trakcie przeprowadzania analizy 8D zespół na bieżąco komunikował się z kierownictwem oraz zawiadamiał o postępach w wyjaśnianiu przyczyn wystąpienia niezgodności wyrobu. Lider zespołu zaprezentował kierownictwu najistotniejsze spostrzeżenia zdobyte $\mathrm{w}$ trakcie fazy D3.

\section{Krok D4 - identyfikacja potencjalnych przyczyn problemu}

W tej części analizy główny cel stanowiło znalezienie źródłowej przyczyny problemu. Przeprowadzono sesje burzy mózgów. Każdy z członków powołanego zespołu starał się przedstawić jak największą liczbę prawdopodobnych rozwiązań powstałego problemu. Sesja burzy mózgów trwała około 45 minut, a wszystkie podane przez uczestników pomysły zostały na bieżąco zapisywane przez lidera grupy. Następnie zespół przystąpił do ich dogłębnej analizy.

Najczęstszym wśród pojawiających się rozwiązań był nieodpowiedni stan techniczny maszyny. Uczestnicy burzy mózgów doszli do wniosku, że najprawdopodobniej miało miejsce niewłaściwe ustawienie okleiny na rolkach dociskowych urządzenia Askla, a co za tym idzie - nieprawidłowe przytwierdzenie okleiny do ramiaka pionowego, oraz nieodpowiednia temperatura koła dociskającego okleinę do ramiaka. Operator urządzenia mógł nie dostrzec złego ustawienia taśmy okleiny 
na rolkach urządzenia, przez co zdarzenie nie zostało zgłoszone do kierownika linii i nie wprowadzono natychmiastowych działań zaradczych.

Kolejnym krokiem analizy problemu było dokładne sprecyzowanie i uściślenie najważniejszych przyczyn problemu wyróżnionych podczas sesji burzy mózgów. Zespół badawczy wyróżnił następujące przyczyny:

zły proces produkcyjny - niewystarczająca ilość topliwego kleju na okleinie, nieodpowiednie warunki atmosferyczne wewnątrz hali produkcyjnej, nieodpowiednie warunki przechowywania okleiny, zużycie sprężyny służącej do napinania foli okleiny, zużycie rolek służących do pozycjonowania folii okleiny, nieodpowiedni transport ramiaków pionowych ze stanowiska Touchwood Askla, zużyte ostrze piły odcinającej okleinę, przepalona spirala grzałki, awaria węża powietrza, poluzowanie ramy Touchwoodu, przestawiony siłownik do opuszczania taśmy.

W Tabeli 2 przedstawiono rodzaje i liczbę występowania przyczyn, które miały miejsce na badanym stanowisku roboczym.

Tabela 2. Rodzaje i liczba występujących przyczyn niezgodności wyrobu w ciągu trzech kwartałów roku 2017

\begin{tabular}{|c|l|c|}
\hline Nr wady & \multicolumn{1}{|c|}{ Opis wady } & Liczba wystąpień \\
\hline 1. & Zużycie sprężyny służącej do napinania folii okleiny & 74 \\
\hline 2. & $\begin{array}{l}\text { Zużycie rolek służących do pozycjonowania folii oklei- } \\
\text { ny }\end{array}$ & 16 \\
\hline 3. & Zużyte ostrze piły odcinającej okleinę & 9 \\
\hline 4. & Przepalona spirala grzałki & 8 \\
\hline 5. & Poluzowanie ramy Touchwoodu & 6 \\
\hline 6. & $\begin{array}{l}\text { Zły proces produkcyjny - niewystarczająca ilość topli- } \\
\text { wego kleju na okleinie }\end{array}$ & 3 \\
\hline 7. & Nieodpowiednie warunki przechowywania okleiny & 3 \\
\hline 8. & Awaria węża powietrza & 2 \\
\hline 9. & $\begin{array}{l}\text { Nieodpowiedni transport ramiaków pionowych ze } \\
\text { stanowiska Touchwood Askla }\end{array}$ & 1 \\
\hline 10. & Przestawiony siłownik do opuszczania taśmy & 3 \\
\hline 11. & $\begin{array}{l}\text { Nieodpowiednie warunki atmosferyczne wewnątrz } \\
\text { hali produkcyjnej }\end{array}$ & \\
\hline
\end{tabular}

Źródło: Opracowanie własne

Zgodnie z Tabela 2 zużycie sprężyny służącej do napinania foli okleiny występuje najczęściej, a tym samym powoduje największą liczbę niezgodności (74). Nie 
bez znaczenia jest również szybkie zużywanie rolek służących do pozycjonowania folii okleiny oraz zbyt późne wymiany tej części urządzenia, co spowodowało powstanie 16 niezgodnych sztuk wyrobu. Wśród wymienionych przyczyn występowania wady najmniejszą liczbę niezgodności spowodowały nieodpowiednie warunki atmosferyczne wewnątrz hali produkcyjnej oraz przestawiony siłownik do opuszczania taśmy.

Następnie przy użyciu diagramu Pareto-Lorenza określono, które przyczyny wystąpienia analizowanej niezgodności wyrobu są najważniejsze z punktu widzenia firmy ERKADO.

Przy użyciu diagramu Pareto-Lorenza możliwe jest określenie częstotliwości występowania przyczyn zaistniałego problemu, co umożliwia wyznaczenie działań niezbędnych do doskonalenia procesów oraz zwiększenia jakości wyrobów. W Tabeli 3 przedstawione zostały przyczyny pojawienia się wady, uszeregowane $\mathrm{w}$ porządku malejącym wspólnie $\mathrm{z}$ obliczonym procentowym udziałem i wartościami skumulowanymi. Pozwala to na zidentyfikowanie niewielkiej liczby przyczyn nieprawidłowości ramiaka skrzydła drzwi, które powodują najdotkliwsze skutki.

Tabela 3. Rodzaje i liczba wystąpień przyczyn niezgodności wyrobu w badanym okresie

\begin{tabular}{|c|c|c|c|c|}
\hline $\begin{array}{l}\mathrm{Nr} \\
\text { wady }\end{array}$ & Opis wady & $\begin{array}{c}\text { Liczba } \\
\text { wystąpień }\end{array}$ & $\begin{array}{l}\text { Udział } \\
\text { procentowy }\end{array}$ & $\begin{array}{c}\text { Wartość } \\
\text { skumulowana }\end{array}$ \\
\hline 1. & $\begin{array}{l}\text { Zużycie sprężyny służącej do napi- } \\
\text { nania foli okleiny }\end{array}$ & 74 & $57,81 \%$ & $57,81 \%$ \\
\hline 2. & $\begin{array}{l}\text { Zużycie rolek służących do pozy- } \\
\text { cjonowania folii okleiny }\end{array}$ & 16 & $12,50 \%$ & $70,31 \%$ \\
\hline 3. & $\begin{array}{l}\text { Zużyte ostrze piły odcinającej } \\
\text { okleinę }\end{array}$ & 9 & $7,03 \%$ & $77,34 \%$ \\
\hline 4. & Przepalona spirala grzałki & 8 & $6,25 \%$ & $83,59 \%$ \\
\hline 5. & Poluzowanie ramy Touchwoodu & 6 & $4,69 \%$ & $88,28 \%$ \\
\hline 6. & $\begin{array}{l}\text { Niewystarczająca ilość } \\
\text { topliwego kleju na okleinie }\end{array}$ & 5 & $3,91 \%$ & $92,19 \%$ \\
\hline 7. & $\begin{array}{l}\text { Nieodpowiednie warunki prze- } \\
\text { chowywania okleiny }\end{array}$ & 3 & $2,34 \%$ & $94,53 \%$ \\
\hline 8. & Awaria węża powietrza & 3 & $2,34 \%$ & $96,87 \%$ \\
\hline 9. & $\begin{array}{l}\text { Nieodpowiedni transport } \\
\text { ramiaków pionowych ze } \\
\text { stanowiska Touchwood Askla }\end{array}$ & 2 & $1,56 \%$ & $98,44 \%$ \\
\hline 10. & $\begin{array}{l}\text { Przestawiony siłownik do opusz- } \\
\text { czania taśmy }\end{array}$ & 1 & $0,78 \%$ & $99,22 \%$ \\
\hline \multirow[t]{2}{*}{11.} & $\begin{array}{l}\text { Nieodpowiednie warunki atmosfe- } \\
\text { ryczne wewnątrz hali produkcyjnej }\end{array}$ & 1 & $0,78 \%$ & $100,00 \%$ \\
\hline & Razem & 128 & & \\
\hline
\end{tabular}


Źródło: Opracowanie własne

Na podstawie określonych oraz odpowiednio ułożonych przyczyn niezgodności z Tabeli 3 zespół wykonał diagram Pareto-Lorenza, który przedstawiony został na Rysunku 1.

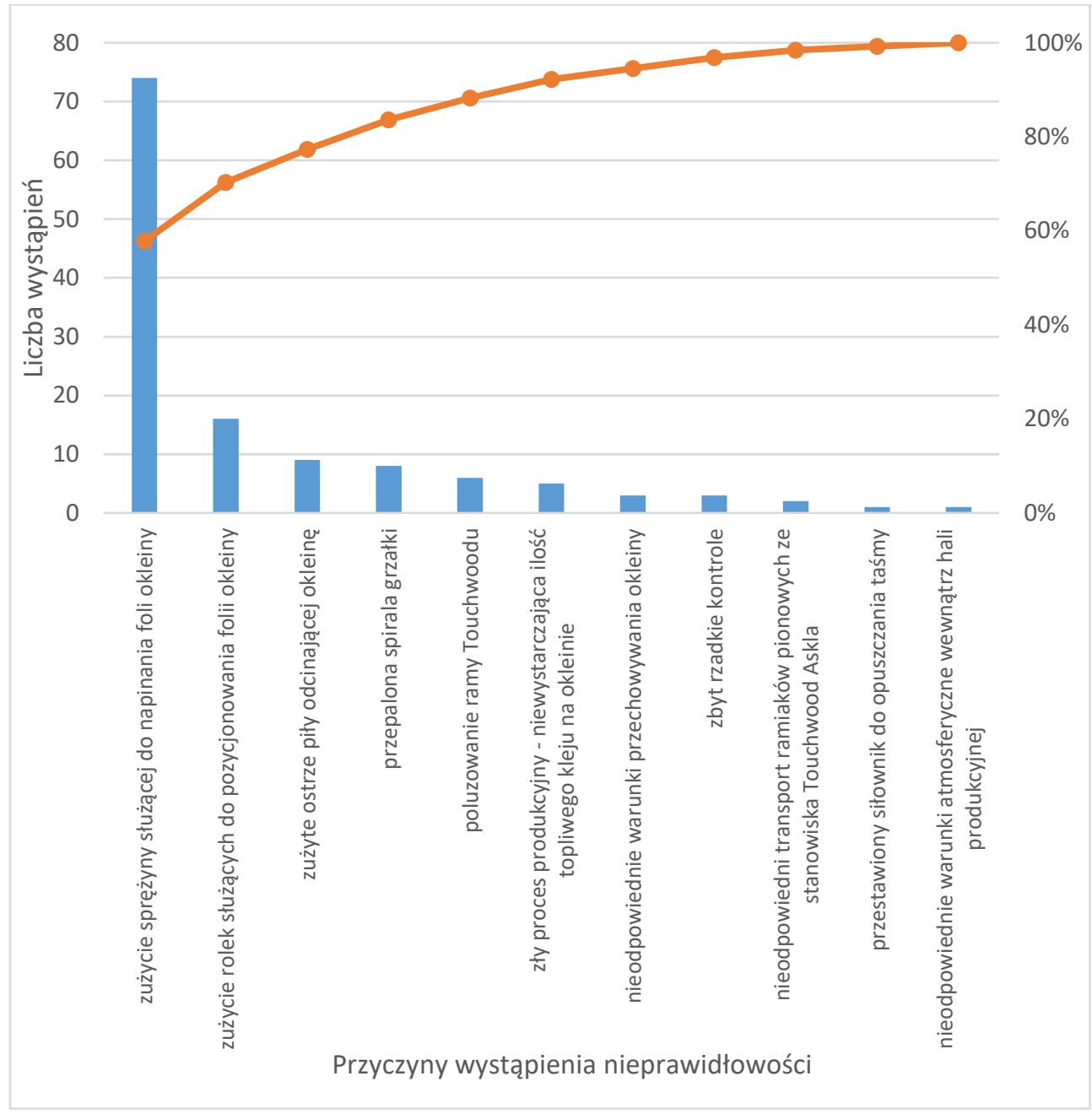

\section{Rysunek 1. Diagram Pareto-Lorenza przyczyn wystąpienia nieprawidłowości wyrobu}

Źródło: Opracowanie własne

W oparciu o przeprowadzoną analizę sporządzoną przy użyciu diagramu Pareto-Lorenza dostrzec można, iż największy procentowy udział mają dwie przyczyny: „zużycie sprężyny służącej do napinania foli okleiny” - ponad $57 \%$ i „zużycie rolek służących do pozycjonowania folii okleiny" - 12,50\%. W pierwszej kolejności działań zaradczych zespół postanowił wyeliminować pierwszą przyczynę nie- 
zgodności ramiaka pionowego, ponieważ stanowi ona ponad połowę wszystkich stwierdzonych przyczyn.

\section{Krok D5 - określenie działań korygujących}

Po dokonaniu analizy znalezionych w uprzednim etapie metody 8D przyczyn źródłowych zaistniałego problemu członkowie powołanej grupy badawczej przystąpili do poszukiwania najlepszych zaradczych działań, które pozwolą na zmniejszenie lub całkowite wyeliminowanie niezgodności.

Ze względu na fakt, iż większość przyczyn powodujących analizowaną niezgodność wyrobu związanych jest ze stanem technicznych urządzenia Askla, zespół badawczy postanowił w przyszłości wdrożyć, najpierw na stanowisku roboczym Touchwood Askla, a następnie w obszarze całej linii produkcyjnej, jedną $\mathrm{z}$ metod Lean Management, jaką jest kompleksowa obsługa parku maszyn (TPM Total Productive Maintenance). Działania zapobiegawcze realizowane będą w dwóch obszarach, tj.: człowieka i maszyny. Zadaniem TPM w pierwszym obszarze będzie zwiększanie poziomu efektywności pracowników poprzez poszerzenie ich wiedzy oraz umiejętności - co będzie równoznaczne ze zwiększeniem stopnia ich odpowiedzialności. Zgodnie $\mathrm{z}$ założeniami pracownicy staną się w większym stopniu zaangażowani w swoją pracę, nabędą umiejętność właściwego interpretowania zaistniałych sytuacji w obrębie ich stanowiska roboczego, a co za tym idzie - będą samodzielnie podejmować stosowne decyzje. Natomiast z perspektywy maszyn działalność pracowników powinna koncentrować się na utrzymaniu maszyny Askla w stanie wysokiej dostępności tak, aby dział utrzymania ruchu uzyskiwał od operatorów informacje na temat aktualnego stanu parku maszynowego w celu bieżącego planowania działań. Dzięki odpowiedniemu poznaniu maszyn pracownicy produkcyjni, pracownicy utrzymania ruchu oraz technolodzy w celu ułatwienia konserwacji bądź usprawnienia maszyn sporządzają projekty ulepszeń (np. pomysły Kaizen). Zaś służby utrzymania ruchu zmieniają nastawienie z reakcyjnego na predykcyjną obsługę maszyn, co przyczyni się do wzrostu dostępności maszyn, a także ich niezawodności, co z kolei w sposób bezpośredni zmniejsza koszty wytwarzania, a co za tym idzie - powiększa zyski przedsiębiorstwa.

Istotna jest również zmiana procesu technologicznego (zwiększenie ilości kleju termoaktywnego), a następnie przestrzeganie na bieżąco zapisów w karcie technologicznej. Należy również sprawować stały nadzór pracowników, a także prowadzić kontrolę procesu technologicznego.

Dodatkowym działaniem naprawczym jest dostosowanie warunków magazynowania oraz warunków panujących wewnątrz hali produkcyjnej do specyfikacji okleiny. Podjęta zostanie również stała kontrola warunków atmosferycznych na terenie zakładu.

\section{Krok D6 - pomiar skuteczności działań korygujących}

Po wdrożeniu działań naprawczych każdy ramiak pionowy po przytwierdzeniu okleiny Toutchwood na jego powierzchnię podlega dodatkowej, dokonywanej przez operatorów kontroli wizualnej poprawności wykonania wyrobu. Działanie to przyczyni się do ograniczenia wystąpienia podobnych niezgodności wyrobu 
w przyszłości oraz do oddzielenia, na tym etapie procesu produkcyjnego, wyrobów niezgodnych od dalszych procesów produkcyjnych.

Dodatkowo wypełniona karta działań korygujących przekazana zastanie liderowi zespołu, którego zadaniem będzie ocena skuteczności wykonanych działań w terminie, który wynika ze specyfiki niezgodności wyrobu, bądź przekazanie karty audytorowi, celem dokonania audytu sprawdzającego. Ocena skuteczności wdrożonych działań może zostać zrealizowana w ramach audytu sprawdzającego czy też przeglądu systemu zarządzania jakością. W przypadku audytu sprawdzającego rejestrowany jest numer, zakres oraz termin audytu. Dalsza metodyka jest analogiczna jak w przypadku przeprowadzania audytu planowego. Ocena skuteczności wdrożonych działań korygujących dokonywana jest przez audytora i zawarta jest $\mathrm{w}$ raporcie $\mathrm{z}$ audytu.

\section{Krok D7 - zapobieganie ponownemu wystąpieniu}

Po dokonaniu obserwacji skuteczności wdrożonych działań naprawczych na stanowisku Touchwood Askla oraz do procesu w kroku D5 zespół badawczy postanowił na stałe wprowadzić jedną z metod Lean Management, jaką jest TPM. Metoda ta służy zapewnieniu maksymalnej efektywności maszyn oraz urządzeń. Przy czym efektywność ta pojmowana jest jako wykorzystanie w maksymalny sposób dostępnego czasu maszyny do wyprodukowania wyrobów dobrej jakości. Dokonano również zmian w procesie produkcyjnym, gdyż zbyt mała ilość kleju na folii okleiny Touchwood była przyczyną nieprawidłowego przylegania okleiny do płaszczyzny ramiaka pionowego. Ważnym zagadnieniem jest również dostosowanie warunków magazynowania oraz warunków panujących wewnątrz hali produkcyjnej do specyfikacji okleiny, co przyczyni się do poprawy jakości produkowanych wyrobów w przedsiębiorstwie ERKADO.

Przeprowadzoną analizę drobiazgowo omówiono z kierownictwem. Lider powołanego zespołu szczegółowo przedstawił każdy z przeprowadzonych kroków w zakresie metody $8 \mathrm{D}$. Kierownictwo postanowiło wprowadzić także szkolenia dla pracowników ERKADO na temat wagi wprowadzonych zmian. Podniesienie ich świadomości nie tylko z zakresu znajomości maszyn i urządzeń na własnych stanowiskach roboczych, lecz również z zakresu znaczenia wprowadzonych zmian. $\mathrm{Z}$ pewnością pozytywnie przyczyni się to do zmniejszenia lub całkowitego wyeliminowania niezgodności wyrobu.

\section{Krok D8 - zamknięcie}

Proces przeprowadzania analizy 8D problemu, jakim było niedoklejenie taśmy Tootchwood w ramiaku pionowym skrzydła drzwiowego wewnątrzlokalowego ramiakowego STILE, trwał dwa tygodnie. Powołany zespół spotykał się kilkukrotnie w celu wymiany swoich poglądów czy pomysłów przyczyn wystąpienia problemu oraz w celu uzgodnienia działań zaradczych. Przez kilka dni zespół obserwował, czy wprowadzone do procesu działania naprawcze przynoszą oczekiwane efekty. Członkowie zespołu dokonywali pomiarów oraz analiz. Wielokrotnie prowadzone były rozmowy z kierownictwem oraz pracownikami. 
Każdemu z członków zespołu serdecznie podziękowano i pogratulowano rozwiązania problemu. Lider również podziękował za współpracę oraz za wszystkie pomysły i wysiłki włożone w rozwiązanie problemu przez każdego z uczestników.

Po dokonaniu kroków metody $8 \mathrm{D}$ sporządzono obszerny i wnikliwy raport $8 \mathrm{D}$ oraz wyciągnięto wnioski do przyszłych analiz i opracowania procedury postępowania z wyrobem niezgodnym. Do głównych spostrzeżeń (wniosków) zaliczono:

konieczność umiejętnego doboru składu zespołu 8D,

przygotowanie pomieszczenia do prac zespołu $8 \mathrm{D}$,

konieczność wcześniejszego zgromadzenia materiałów biurowych niezbędnych do prac zespołu 8D,

- $\quad$ być może wcześniejsze przeszkolenie co najmniej niektórych członków zespołu

- $\quad 8 \mathrm{D}$ z metodyki pracy zespołowej, instrumentów zarządzania jakością.

Można mieć nadzieję, że na podstawie tej analizy sporządzona procedura postępowania $\mathrm{z}$ wyrobem niezgodnym inspirowana metodą $8 \mathrm{D}$ przyczyni się do efektywniejszego rozwiązywania problemów jakościowych w firmie ERKADO.

\section{Podsumowanie}

Zachodzące zmiany w gospodarce sprawiły, że jakość wyrobów stała się jednym z najważniejszych kryteriów, które decydują o odniesieniu przez przedsiębiorstwo produkcyjne sukcesu na rynkach zbytu. Nierzadko błędne rozwiązywanie powstających problemów oraz nieodpowiednie działania kadr spowodowały, iż znaczna ilość zakładów produkcyjnych przestała istnieć. Aby w przyszłości uniknąć tego typu problemów, należy pogłębiać wiedzę dotyczącą udoskonalania przedsiębiorstwa oraz stosować sprawdzone metody i narzędzia zarządzania jakością.

Celem artykułu było przeprowadzanie analizy wykorzystania metody 8D do rozwiązania problemu związanego z reklamacją klienta, tj. niedostatecznego przylegania folii okleiny do ramiaka pionowego skrzydła drzwi wewnątrzlokalowych STILE. W etapie 4D - identyfikacja potencjalnych przyczyn - wykonano sesje burzy mózgów, przy pomocy której wyszczególnione zostały potencjalne przyczyny występowania niezgodności wyrobu. $\mathrm{Na}$ tej podstawie wykonano diagram Pareto-Lorenza, którego celem było zidentyfikowanie najbardziej istotnych spośród znacznej liczby przyczyn problemu oraz zaproponowanie i wdrożenie działań korygujących. Wyciągnięte wnioski to krok w kierunku lepszego realizowania metody $8 \mathrm{D}$, być może już $\mathrm{w}$ ramach opracowanej procedury.

1.

\section{Literatura}

Antosz K., Pacana A., Stadnicka D., Zielecki W. (2013), Narzędzia Lean Manufacturing, Oficyna Wydawnicza Politechniki Rzeszowskiej, Rzeszów.

Babica M., Pająk E., (2006a), Koncepcja metody eliminacji niezgodności w procesach produkcyjnych, „Zeszyty Naukowe Politechniki Poznańskiej. Budowa Maszyn i Zarządzanie Produkcją", nr 3, s. 5-15. 
Babica M., Pająk E. (2006b), Model efektywnej metody rozwiazywania problemów, [w:] Knosla R. (red.), Komputerowo zintegrowane zarządzanie, t. 1, Oficyna Wydawnicza Polskiego Towarzystwa Zarządzania Produkcją, Opole, s. 46-54.

Babuśka Ł., Kluczek A. (2009), Rozwiązywanie problemów w motoryzacji, „Przegląd Techniczny. Gazeta Inżynierska", nr 24, s. 7-8.

Ćwiklicki M., Obora H. (2009), Metody TQM w zarządzaniu firma, Poltext, Warszawa.

Dahlgaard J., Kristen K., Kanji K.G. (2000), Podstawy zarządzania jakościa, Wydawnictwo Naukowe PWN, Warszawa.

Francik K., Pudło M. (2016), Systemy wspomagania decyzji w aspekcie zarządzania ryzykiem w przedsiębiorstwie, „Zeszyty Naukowe Politechniki Częstochowskiej. Zarządzanie”, nr 22, t. 1, s. 23-32. DOI: 10.17512/znpcz.2016.2.02

Huber Z. (2007), Analiza FMEA procesu. Kawa na ławę, Internetowe Wydawnictwo Złote Myśli, Gliwice.

Łasiński G. (2007), Rozwiązywanie problemów w organizacji. Moderacje w praktyce, PWE, Warszawa.

8. $\quad$ Łuczak J., Maćkiewicz E. (2006), 8D oraz inne metody zarzadzania jakościa w branży motoryzacyjnej (OE/OES) - analiza przypadku, „Problemy Jakości”, nr 11, s. 35-43.

9. $\quad$ Łuczak J., Matuszak-Flejszman A. (2007), Metody i techniki zarządzania jakością. Kom10. pendium wiedzy, Quality Progress, Poznań.

Mazur A., Gołaś H. (2010), Zasady, metody i techniki wykorzystywane w zarzadzaniu jako-

11. ścia, Wydawnictwo Politechniki Poznańskiej, Poznań.

12. Midor K. (2014), An Analysis of the Causes of Product Defects Using Quality Management Tools, „Management Systems in Production Engineering”, Vol. 16, No. 4, s. 162-167. DOI:

13. 10.12914/MSPE-04-04-2014

Rumocka A. (2016), Funkcjonowanie organizacji inteligentnej na przykładzie mikroprzedsiębiorstwa „B+R Studio Analizy Rynku Meblarskiego”, „Zeszyty Naukowe Politechniki Częstochowskiej. Zarządzanie", nr 23, t. 1, s. 169-178. DOI: 10.17512/znpcz.2016.3.1.17 Szczepańska K. (2009), Metody i techniki TQM, Oficyna Wydawnicza Politechniki Warszawskiej, Warszawa.

\title{
USE OF THE METHOD 8D FOR SOLVING QUALITY PROBLEM
}

\begin{abstract}
The aim of this article is to analyze the incompatibility of the product presented in connection with the customer complaint, ie the insufficient adhesion of the veneer film to the vertical stile of the STILE inner door leaf. The publication examines the use of one of the $8 \mathrm{D}$ method of quality management. It was used to solve the problem of non-compliant products in ERKADO. The idea behind the method is to correctly identify the cause of the problem and to apply such corrective measures to prevent the problem from occurring again.
\end{abstract}

Keywords: method 8D, brainstorming, Pareto-Lorenz diagram, quality management, quality management methods 